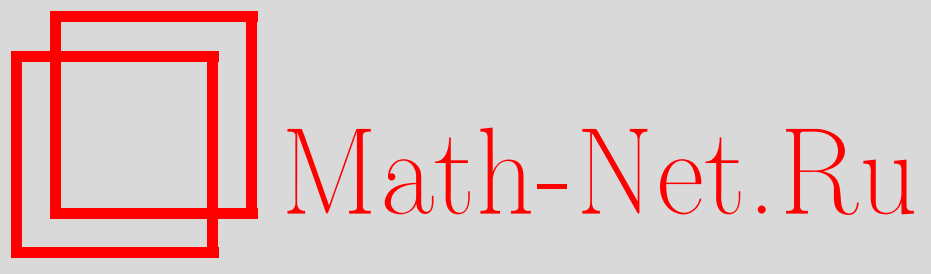

В. Птушенко, Я к вам травою прорасту, Квант, 2018, номер 9, 4950

DOI: https://doi.org/10.4213/kvant20180906

Использование Общероссийского математического портала Math-Net.Ru подразумевает, что вы прочитали и согласны с пользовательским соглашением

http://www . mathnet.ru/rus/agreement

Параметры загрузки:

IP : 54.237 .206 .68

26 апреля 2023 г., 11:09:24

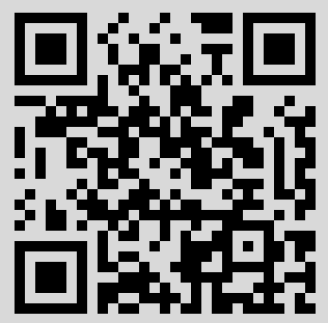




\section{Я к вам травою прорасту}

\section{В.ПТУШЕНКО}

Ж ИТЕЛЯМ ГОРОДОВ ПРИВЫЧНО ВИдеть, как хрупка и беззащитна природа перед натиском цивилизации. Но тем более необычно наблюдать, как она способна восстанавливаться, преодолевая самые невероятные барьеры. Удивительно, как нежный, мягкий стебелек растения пробивается через асфальт, выдерживающий напор тысяч колес. Не менее удивительно и то, что растения могут селиться на стенах. Травинки, пробивающиеся через щели между кирпичами или каменными плитами облицовки зданий, можно наблюдать в городе на стенах вполне жилых, «действующих» зданий. Там же, где влияние человека меньше - на верхних этажах и крышах или на стенах заброшенных строений, - можно встретить порой целые рощицы (рис.1).

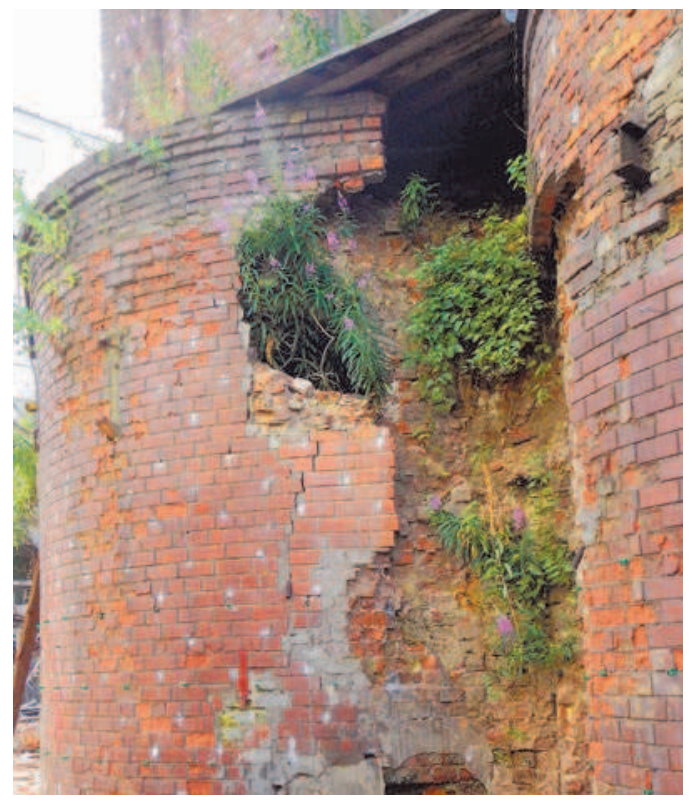

PUC. 1

DOI: https://doi.org/10.4213/kvant20180906
Одно из принципиальных условий для жизни растений - наличие необходимых для роста минеральных элементов в той среде, в которой находятся его корни. Стены заброшенных церквей, например, чаще всего сделаны из красного кирпича. Основным сырьем для него служит глина - конечно, не самый плодородный вариант почвы, но все же содержащий многие элементы, являющиеся первостепенными для растения: элементы металлов (в виде оксидов) - калия, натрия, кальция, магния, железа, а также серу. Из жизненно важных элементов в этом списке не хватает азота и фосфора.

$\mathrm{C}$ необходимостью внесения в почву азотных удобрений человеку приходится сталкиваться и в обычной среде роста растений. В дикой природе азот попадает в почву благодаря деятельности микроорганизмов - бактерий, способных превращать в органические вещества азот воздуха. Огородники хорошо знают, что такие бактерии содержатся в клубеньках бобовых растений. Однако этим полезным делом способны заниматься и свободноживущие бактерии, в частности фотосинтезирующие цианобактерии, готовые поселяться где угодно - в водоемах, на поверхности почвы, на стенах, на стенках аквариумов и горшков с домашними растениями, образуя зеленый налет. Вполне возможно, что именно они, поселяясь рядом со злаками или молодыми березками, обеспечивают приток азота в среду жизни своих соседей.

Сложнее обстоит дело с фосфором. Может быть, его заносят животные - муравьи, мыши, птицы? Впрочем, и в этом отношении условия жизни на стене не сильно отличаются от жизни в обычной почве - там тоже всегда плохо с фосфором. Кроме того, все необходимые элементы, включая фосфор, содержатся и в цементе, скрепляющем кирпичи.

Конечно, говоря о химическом составе кирпичного субстрата, мы упустили один важный этап: нужно еще, чтобы кирпич превратился в подходящую для роста растений рыхлую среду. Отчасти это происходит в силу естественной эрозии - под действием атмосферных осадков. Кроме того, «стартовую площадку» для семян растений могут создать и скопления пыли - т.е. частичек того же самого грунта, заметенного ветром в щели между кирпичами или пли- 
тами. А дальше уже растение, подкисляя пространство вокруг своих корней и с усилием (используя силы осмоса) пробивая их вперед, само способно постепенно разрушать твердый строительный материал, превращая его в более рыхлый, в котором легче удерживается влага. Так что проблема водного питания также постепенно разрешается, хотя иссушается эта среда в летнее время все же сильнее, чем почва. А зимой она сильнее промерзает, и это еще одно испытание для корней обитателей стен.

Однако это - закрепление на уже занятом участке, а сначала нужно еще заселить его. Интересно посмотреть, какие растения чаще всего поселяются на стенах. Из деревьев обычно это береза, обладающая очень мелкими летучими семенами (рис.2). Из травя-

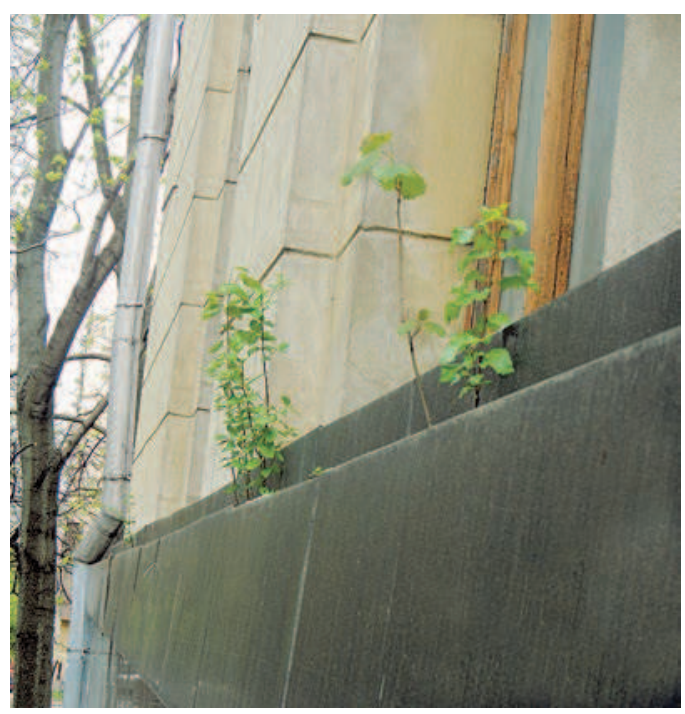

Pис. 2

нистых растений обычны мхи и папоротники, которые распространяются еще более легкими спорами, иван-чай с хохлатыми (с «парашютиками») семенами и другие растения-первопроходцы (рис.3).

Как видно, удивительные способности растений выживать в неподходящих, на первый взгляд, условиях, вполне объяснимы. Тем не менее, даже после этих объяснений фотография, приведенная здесь на рисунке 4 и на четвертой странице обложки журнала, выглядит невероятной. Причем автомобиль, у которого почти на лобовом стекле вырос этот маленький зеленый побег, отнюдь не

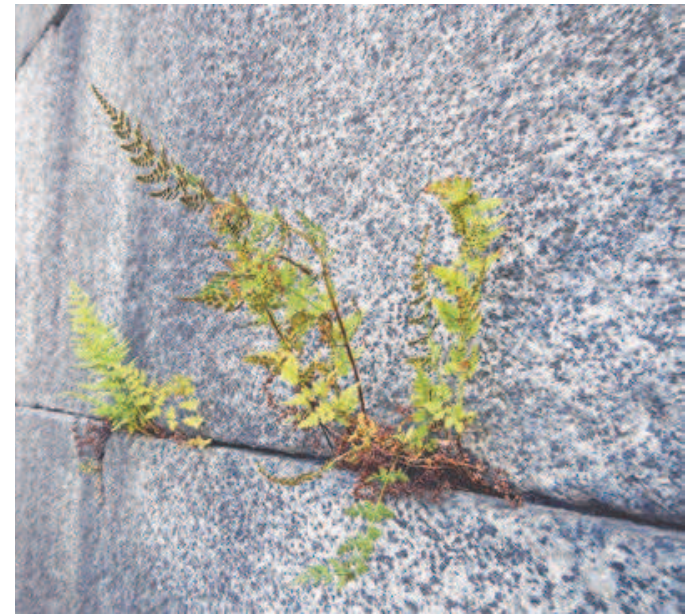

Pис. 3

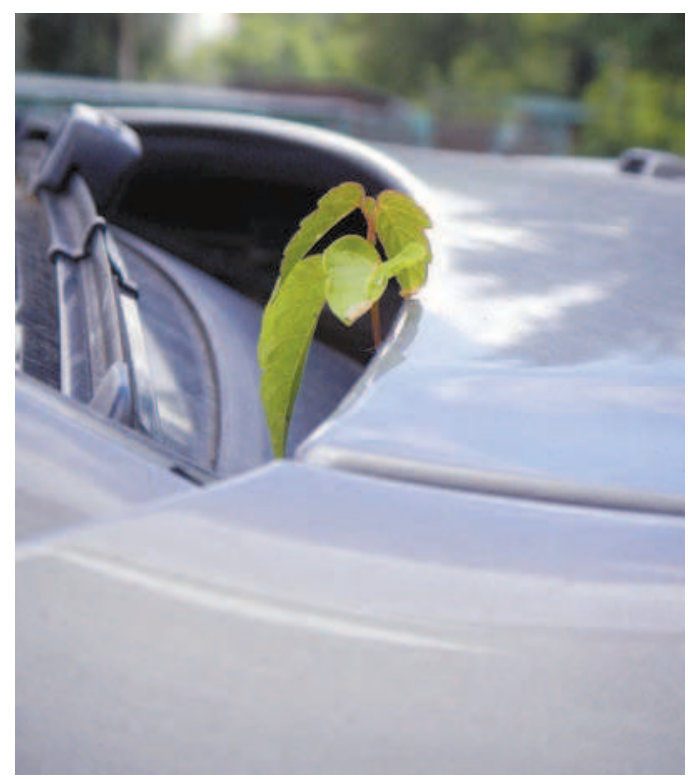

Puc. 4

старый и заброшенный, а современный, хорошо ухоженный и, очевидно, регулярно используемый своими хозяевами. А значит, чтобы вырасти на пылевом субстрате, у ростка было всего несколько дней. Да и количество этого субстрата, которое могло успеть накопиться в какой-нибудь щели кузова, совсем мизерное.

Автор благодарен В.В.Чубу за советы и критические замечания. 